\title{
HOW MANY RIVER OTTERS INHABIT YELLOWSTONE LAKE? AN ASSESSMENT WITH FECAL AND HAIR DNA ANALYSES
}

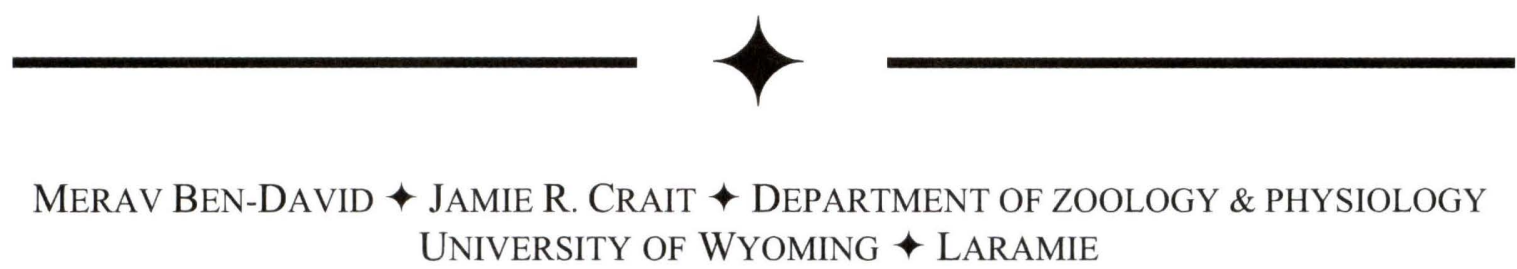

\section{$\downarrow$ JUSTIFICATION AND OBJECTIVES}

River otters (Lontra canadensis) in Yellowstone Lake are different from most other otter populations in that they are heavily dependent on one prey species - Yellowstone cutthroat trout (Oncorhynchus clarki bouvieri; Crait and Ben-David 2006, Crait et al. 2006). Our 2002-2003 studies in Yellowstone Lake showed that cutthroat trout were the most common prey item in otter scats throughout the summer. Overall, trout occurred in $72 \%$ and longnose suckers (Catostomus catostomus) in $43 \%$ of otter feces, based on 515 samples identified to the family-level and 110 samples analyzed to the species-level. Suckers were more prevalent than trout in otter scats only on tributary streams, towards the end of the cutthroat trout spawning season. Introduced lake trout (Salvelinus namaycush), which inhabit deep water and are largely inaccessible to otters, occurred in less than $5 \%$ of otter scats. In addition, based on fecal deposition rates, we established that otters were more active on spawning streams and less active along the Yellowstone Lake shoreline during the height of the cutthroat trout spawning season, with a return to elevated activity on the lake after spawning had ended (Crait and Ben-David 2006). Therefore, because of the lack of a suitable alternative prey, it is likely that a decline in cutthroat trout (Koel et al. 2005) will translate into a decline in the abundance of otters in this system. Indeed, our 2002-2003 survey indicates the number of river otter latrine sites in the
Yellowstone Lake ecosystem is lower than expected based on similar surveys in the Rocky Mountain region (Crait and Ben-David unpublished data).

Yellowstone Lake river otters appear to be unique in yet another respect. In 2005, we compared diving physiology of river otters at sea level (San Juan Islands, Washington, USA) with those from the high-altitude $(2357 \mathrm{~m})$ Yellowstone Lake population. Preliminary results suggest unique physiological differences in the Yellowstone Lake population relative to lowland otters (Crait et al. in prep). Otters from both populations appear to have a higher maximal oxygen $\left(\mathrm{O}_{2}\right)$ carrying capacity than terrestrial mammals of similar body size likely due to the increased $\mathrm{O}_{2}$ demands of diving (Kooyman 1989). However, Yellowstone Lake otters seem to have lower hemoglobin $(\mathrm{Hb})-\mathrm{O}_{2}$ binding affinity and a higher $\mathrm{O}_{2}$ carrying capacity than those of the sea level animals. This is likely a compensatory response to moderate hypoxia which may enhance delivery of $\mathrm{O}_{2}$ to tissues (Banchero and Grover 1972, Storz 2007). Our results suggest that otters in Yellowstone Lake have alterations to their $\mathrm{Hb}$ complex or blood chemistry. This is possibly due to increases in 2,3-diphosphoglyceric acid (DPG) in red blood cells (Pomponi et al. 2004) that allow $\mathrm{O}_{2}$ delivery to tissues at a $\mathrm{PO}_{2}$ lower than experienced by conspecifics at sea level. Because of this unique physiological adaptation to diving at high altitude, and the potential threat of population declines as a result of loss of their 
primary prey, monitoring the status of river otters in Yellowstone Lake should become a priority.

Our objectives are:

1. Estimate the abundance of river otters in Yellowstone Lake in 2002-2003 and in 20062008.

2. Estimate survival of river otters in Yellowstone Lake in 2002-2003 and in 20062008.

3. Compare estimates of abundance and survival between these two time periods and related them to indices of cutthroat trout abundance.

4. Quantify the relatedness of individuals during the two time periods to assess whether reproductive success has decline between the two time periods.

5. Develop spatially-explicit individual based models that link predation of river otters on cutthroat trout with their subsequent survival, reproduction, and densities.

\section{$\downarrow$ SIGNIFICANCE}

Despite occurring in one of the most protected areas in North America - Yellowstone National Park - river otters inhabiting Yellowstone Lake may be threatened if declines of native cutthroat trout continue. Because of their high dependency on this one prey species, and an apparent lack of ability to switch to alternative prey such as the invasive lake trout, river otters could decline together with their primary prey. Otters will probably persist in other areas of Yellowstone National Park, but these individuals will be less likely to possess the special physiological adaptation for diving at high altitude because they usually forage in shallow streams where such adaptation is less essential. Also, because few otter populations occur in high altitude lakes (Melquist et al. 2003) this adaptation may be unique to Yellowstone Lake otters. Thus, it is imperative to evaluate changes in the abundance of river otters in Yellowstone Lake between 2002-2003 and 20062008, develop models linking the abundance of otters with that of Yellowstone cutthroat trout, and develop protocols for future non-invasive monitoring of this unique otter population.

\section{Methods AND RESUlts TO DATE}

Sample collection - From the end of May to mid-August in 2002 and 2003, we surveyed $152.8 \mathrm{~km}$ and $177.3 \mathrm{~km}$, respectively, of the lake shoreline from a small boat. A total of $64.7 \mathrm{~km}$ in 2002, and $104.4 \mathrm{~km}$ in 2003 of tributary streams were surveyed on foot. During these surveys we identified 94 river otter latrine sites. Each site was visited 1-6 times in each summer and a total of 206 fresh feces were collected for DNA analyses. All fresh otter feces collected during each visit to a latrine were preserved in $100 \%$ ethanol (EtOH ) and stored on ice. In 2006, we revisited 48 of these sites from the end of May to the end of August 7.7 times on average, and collected 85 fresh scats for DNA analyses (Table 1). In 2007, we revisited 47 of the sites 9.0 times on average, and collected 51 fresh feces for DNA analyses (Table 1). In addition, we placed $1-3$ commercial body-snares modified to capture hair at latrine sites with heavy activity (more than 5 feces per site; Figure 1; DePue and Ben-David 2007). The locking mechanism on these snares has been removed and replaced with a paper clip. This modification allows the wire snare to cinch around the otter and then break free with little tension, while retaining hairs from the animal. These snares capture hair from a single individual and thus avoid problems with cross contamination of samples (DePue and BenDavid 2007). Using these snares we collected a total of 75 hair samples in 2006 and 105 in 2007 (Table 1). No animal (otter or other) were restrained by these traps. In 2008, we will repeat sampling of feces and hair from the end of May to the end of August.

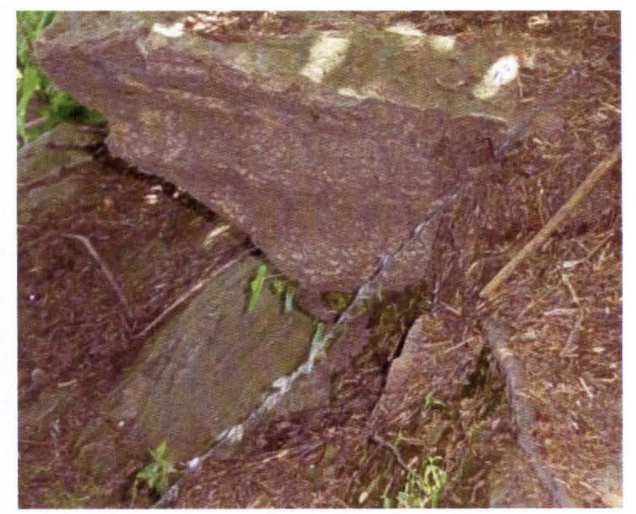

Figure 1 - Clumps of river otter hair snagged off an individual by the barbs on a modified body snare. 


\begin{tabular}{cccccccccc}
\hline Year & \multicolumn{3}{c}{ Number of visits } & \multicolumn{3}{c}{ Number of feces per site per visit } & \multicolumn{3}{c}{ Number of hairs per site per visit } \\
\hline \multirow{2}{*}{2002} & Mean & SE & Range & Mean & SE & Range & Mean & SE & Range \\
\cline { 2 - 9 } 2003 & 2.20 & 0.17 & $1-5.00$ & 0.86 & 0.23 & $0-6.00$ & NA & NA & NA \\
2006 & 7.44 & 0.10 & $1-6.00$ & 0.53 & 0.13 & $0-7.50$ & NA & NA & NA \\
2007 & 9.02 & 0.67 & $1-25.00$ & 0.21 & 0.09 & $0-4.00$ & 0.14 & 0.03 & $0-0.77$ \\
& 0.90 & $1-23.00$ & 0.09 & 0.03 & $0-1.00$ & 0.19 & 0.04 & $0-1.00$ \\
\hline
\end{tabular}

Table 1 - Number of visits per site and number of feces and hair samples collected per site per visit from river otter latrine sites in Yellowstone Lake from the end of May to the end of August 2002, 2003, 2006, and 2007.

DNA analyses - Prior to DNA extraction, each fecal sample was sieved through fine-mesh stainless steel, autoclavable sieves to ensure the removal of all hard parts of prey material. This is an important step for improving the quality and quantity of extractable DNA through reducing the extraction and amplification of non-target DNA. Sieving also helps avoid the problem of the uneven distribution of cells shed through the intestinal lining as documented by Kohn et al. (1995). Excess EtOH was evaporated from each sample after sieving in a closed hood. Following the sieving a $200 \mu \mathrm{l}$ sub-sample was used to extract DNA with a QIAamp DNA Mini Kit (QIAGEN Inc, Valencia, CA; Hansen et al. 2008). We used QIAGEN DNeasy tissue extraction kit (QIAGEN Inc, Valencia, CA) to extract DNA from hair. All feces and hair samples collected in 20022003 and 2006-2007 were extracted. We will use similar methods to extract DNA from samples collected in 2008 .

DNA amplifications (PCR) are currently under way. PCR are performed using a PTC-0200 DNA Engine Peltier Thermal Cycler (MJ Research, Inc., Waltham, MA). Primers RIO-01, RIO-05, RIO17, and RIO-19 developed for river otters (Beheler et al. 2004, 2005), and LUT-701, LUT-733, LUT-801, and LUT-829 developed for Eurasian otters (Lutra lutra; Dallas and Piertney 1998) are used in PCR reactions. Positive (blood samples from river otters with known genotypes) and negative (PCR blanks) controls are included with each PCR run in order to ensure the reliability of PCRs and monitor contamination (Hansen et al. 2008). PCR products are resolved on an ABI 3130xl Automated Sequencer (Applied Biosystems Foster City, CA; ABI) with formamide-LIZ ladder, as an internal size standard in each lane. The data will be sized in base pairs and analyzed using ABI software GeneMapper $v 4$ at the Nucleic Acid Exploration Facility at the University of Wyoming.
A consensus genotype will be obtained from positive PCRs with identifiable alleles that have sufficient replication (Goossens et al. 2000). In order to reduce genotyping error and time spent trying to amplify poor quality samples, each sample that does not amplify after four PCR runs with the most reliable marker (RIO-19) will be discarded (Morin et al. 2001, Paetkau 2003). Genotypes will be evaluated after two initial runs (Frantz et al. 2003). Loci that amplify the same heterozygous individual twice will be recorded, and homozygote genotypes will be accepted on a provisional basis after a stepwise amplification approach of up to seven PCRs. In the case that an allele amplifies only once to yield one heterozygote genotype in seven runs with the other six runs resulting in the same homozygous genotype, the allele will be designated as constituting a halfgenotype (Miller et al. 2002, Frantz et al. 2003, 2004).

Estimating abundance, density, and survival of otters - To ensure that the number of loci used is sufficient for individual identification, the probability of identity $\left(P_{\mathrm{ID}}\right.$; the probability that two individuals from a population share the same genotype) will be calculated using the program GIMLET v.1.3.2 (Valiére 2002). We will calculate both the lower limit, $P_{\mathrm{ID}-}$ unbiased, which includes a sample-size correction, and assumes a randomly mating population of unrelated individuals in Hardy-Weinberg equilibrium (Paetkeau 2003), as well as the upper limit, $P_{\mathrm{ID}-\text { sib }}$, which assumes the population only to be composed of siblings (Waits et al. 2001).

To estimate abundance of river otters in Yellowstone Lake, we will develop capture histories for individual river otters based on DNA microsatellite profiles of hair and fecal samples. For example, preliminary analyses of river otter fecal samples collected in Victoria, British Columbia, identified 68 unique individuals that were recaptured between 0 and 6 times. These capture histories translated to an estimate of 72 otters $(95 \%$ confidence interval: 53 - 105; Guertin et al. in prep.). Similarly, 
using capture histories of genotyped individuals, we will employ robust design models in the program MARK (White and Burnham 1999) to estimate the apparent survival and capture probabilities for the 2002-2003 and 2006-2008 time periods (Pollock 1982, Amstrup et al. 2005). Models will be ranked using Akaike Information Criteria corrected for small sample size (AICc; Burnham and Anderson 2002) and evaluated for validity of parameter estimates. Population size will be derived post-hoc based on total number of captures and capture probabilities (Williams et al. 2002a).

Otter densities for each time period will be calculated by dividing the estimated abundance of otters by the length of the shoreline surveyed. Because river otters rarely travel more than a $100 \mathrm{~m}$ from shore (Bowyer et al. 2003), shoreline length represents a better measure of otter distribution than area (Blundell et al. 2001). To compare the estimates of abundance and densities between the two time periods (2002-2003 and 2006-2007), we will use a $t$ test corrected for repeated samples (Zar 1999).

To evaluate temporal changes in reproductive success, we will estimate relatedness of individuals with the program KINSHIP (Queller and Goodnight 1989). We will then compare values of relatedness using a two-tailed Mann-Whitney test with a Monte Carlo estimation of probability $(10,000$ replications) following Fabiani et al. (2006).

Modeling the relation between river otter densities and survival and cutthroat trout decline To establish the degree to which numbers of river otters have declined following the decline of cutthroat trout in Yellowstone Lake, we will use an individual-based bioenergetic model (Grimm and Railsback 2005) to infer supportable otter population sizes in relation to estimates of the availability of cutthroat trout. First, we will estimate the economics of foraging for individual otters, as a function of food availability. Data exist in the literature on energetic costs and duration of foraging (Ben-David et al. 2000, Williams et al. 2002b, Kruuk 2006). National Park Service data on the densities of potential prey fish will be combined with historic size class distributions to infer the average energetic return from a captured fish (Derby and Lovvorn 1997, Ruzycki et al. 2003). We will then calculate the number of foraging bouts required per day and infer a threshold prey density, below which an individual otter will be unable to meet energetic requirements and will either emigrate or die. Once a threshold is established, we will use an individual-based, depletion modeling approach (Grimm and Railsback 2005, Sutherland 2005) to estimate the "carrying capacity" of otters as a function of food availability. The model will be spatially and temporally explicit, and upper limits on otter density will be set by estimates of habitat availability, minimum tolerable home range sizes and group formation (Bowyer et al. 2003, Ben-David et al. 2005, Crait and Ben-David 2007). The final model will be compared with data on historical prey abundance to provide estimates of otter population size, both currently and during recent decades.

\section{$\downarrow \quad$ Literature Cited}

Amstrup, S.C., T.L. McDonald, and B.F.J. Manly. Eds. 2005. Handbook of capture-recapture analysis. Princeton University Press. Princeton, New Jersey.

Banchero, N., and R.F. Grover. 1972. Effect of different levels of simulated altitude on $\mathrm{O}_{2}$ transport in llama and sheep. American Journal of Physiology 222: 1239-1245.

Beheler, A.S., J.A. Fike, G. Dharmarajan, O.E. Rhodes, and T.L. Serfass. 2005. Ten new polymorphic microsatellite loci for North American river otters (Lontra canadensis) and their utility in related mustelids. Molecular Ecology Notes 5: 602-604.

Beheler, A.S., J.A. Fike, L.M. Murfitt, O.E. Rhodes Jr., T.L. Serfass. 2004. Development of polymorphic microsatellite loci for North American river otters (Lontra canadensis) and amplification in related mustelids. Molecular Ecology Notes 4: 56-58.

Ben-David, M., G.M. Blundell, J.W. Kern, J.A.K. Maier, E.D. Brown, and S.C. Jewett. 2005. Communication in river otters: creation of variable resource sheds for terrestrial communities. Ecology 86:1331-1345.

Ben-David, M., T.M. Williams, and O.A. Ormseth. 2000. Effects of oiling on exercise physiology and diving behavior in river otters: a captive study. Canadian Journal of Zoology 78:1380-1390. 
Blundell, G.M., J.A.K. Maier, and E.M. Debevec. 2001. Linear home ranges: effects of smoothing, sample size, and autocorrelation on kernel estimates. Ecological Monographs 71:469-489.

Bowyer, R. T., G. M. Blundell, M. Ben-David, S. C. Jewett, T. A. Dean, and L. K. Duffy. 2003. Effects of the Exxon Valdez oil spill on river otters: injury and recovery of a sentinel species. Wildlife Monographs 153: 1-53.

Burnham, K.P., and D.R. Anderson. 2002. Model selection and multimodel inference: a practical information-theoretic approach. 2nd edition. Springer, New York.

Crait, J.R., and M. Ben-David. 2006. River otters in Yellowstone Lake depend on a declining cutthroat trout population. Journal of Mammalogy 87:485-494.

Crait, J. R., and M. Ben-David. 2007. Effects of river otter activity on terrestrial plants in trophically altered Yellowstone Lake. Ecology 88:1040-1052.

Crait, J.R., G.M. Blundell, K.E. Ott, J.K. Herreman, and M. Ben-David. 2006. Late seasonal breeding of river otters in Yellowstone National Park. American Midland Naturalist 156:189-192.

Crait, J.R., H. D. Prange, N. Marshall, H.J. Harlow, and M. Ben-David. in prep. High altitude diving adaptations of river otters in Yellowstone National Park. Journal of Experimental Biology.

Dallas, J.F., and S.B. Piertney. 1998. Microsatellite primers for the Eurasian otter. Molecular Ecology 7: 1247-1251.

DePue, J.E., and M. Ben-David. 2007. Hair sampling techniques for river otters. Journal of Wildlife Management 71: 671-674.

Derby, C.E., and J.R. Lovvorn. 1997. Predation on fish by cormorants and pelicans in a coldwater river: a field and modeling study. Canadian Journal of Fisheries and Aquatic Sciences 54:1480-1493.
Fabiani, A., F. Galimberti, S. Sanvito, and R. Hoelzel. 2006. Relatedness and site fidelity at the southern elephant seal, Mirounga leonina, breeding colony in the Falkland Islands Animal Behaviour 72:617-626.

Frantz, A.C., L.C. Pope, P.J. Carpenter, T.J Roper, G J .Wilson, R.J .Delahay, and T.Burke. 2003. Reliable microsatellite genotyping of the Eurasian badger (Meles meles) using faecal DNA. Molecular Ecology 12: 1649-1661.

Frantz, A.C., M. Schaul, L.C. Pope, F. Frack, L. Schley, C.P. Muller, and T.J. Roper. 2004. Estimating population size by genotyping remotely plucked hair: the Eurasian badger. Journal of Applied Ecology 41:985-995.

Goossens, B., L. Chikhi, S.S. Utami, J. de Ruiter, and M.W. Bruford. 2000. A multi-samples, multi-extracts approach for microsatellite analysis of faecal samples in an arboreal ape. Conservation Genetics 1:157-162.

Grimm, V., and S.F. Railsback. 2005. Individualbased modeling and ecology. Princeton University Press, Princeton, NJ.

Guertin, D., A. Harestad, M. Ben-David, and J.E. Elliott. in prep. Fecal DNA fingerprinting reveals human-induced effects on densities and vital rates of coastal river otters in southwest British Columbia. Journal of Animal Ecology.

Hansen, H., M. Ben-David, and D.B. McDonald. 2008. Effects of genotyping protocols on success and errors in identifying individual river otters (Lontra canadensis) from their faeces. Molecular Ecology Resources 8:282289.

Koel, T.M., P.E. Bigelow, P.D. Doepke, B.D. Ertel, and D.L. Mahony. 2005. Nonnative lake trout result in Yellowstone cutthroat trout decline and impacts to bears and anglers. Fisheries 30:10-19.

Kohn, M., F. Knauer, A. Stoffella, W. Schroder, and S. Paabo. 1995. Conservation genetics of the European brown bear - a study using excremental PCR of nuclear and mitochondrial sequences. Molecular Ecology 4:95-103. 
Kooyman, G. L. 1989. Diverse divers: physiology and behavior. Springer-Verlag, Berlin.

Kruuk, H. 2006. Otters: ecology, behaviour and conservation. Oxford University Press, Oxford, UK.

Melquist, W. E., and M. G. Hornocker. 1983. Ecology of river otters in west central Idaho. Wildlife Monograph 83: 1-60.

Miller, C. R., P. Joyce, and L. P. Waits. 2002. Assessing allelic drop-out and genotype reliability using maximum likelihood. Genetics 160:357-366.

Morin, P.A., K.E. Chambers, C. Boesch, and L. Vigilant. 2001. Quantitative polymerase chain reaction analysis of DNA from noninvasive samples for accurate microsatellite genotyping of wild chimpanzees (Pan troglodytes verus). Molecular Ecology 10:1835-1844.

Paetkau, D. 2003. An empirical exploration of data quality in DNA-based population inventories. Molecular Ecology 12: 13751387.

Pfeiffer, P., and B.M. Culik. 1998. Energy metabolism of underwater swimming in river-otters (Lutra lutra L.). Journal of Comparative Physiology B 168:143-148.

Pollock, K.H. 1982. A capture-recapture design robust to unequal probability of capture. Journal of Wildlife Management 46:752757.

Pomponi, M., E. Gavuzzo, C. Bertonati, A.E. Derocher, C. Lydersen, O. Wiig, and K. M. Kovacs. 2004. Hemoglobin, $\mathrm{pH}$ and DPG/chloride shifting. Biochimie 86:927932.

Queller, D.C. and K.F. Goodnight. 1989. Estimating relatedness using genetic markers. Evolution 43:258-275.
Ruzycki, J.R., D.A. Beauchamp, and D.L. Yule. 2003. Effects of introduced lake trout on native cutthroat trout in Yellowstone Lake. Ecological Applications 13:23-37.

Storz, J.F. 2007. Hemoglobin function and physiological adaptation to hypoxia in highaltitude mammals. Journal of Mammalogy 88: 24-31.

Sutherland, W.J. 2005. From individual behaviour to population ecology. Oxford University Press, Oxford, UK.

Valière, N. 2002. GIMLET: a computer program for analysing genetic individual identification data. Molecular Ecology Notes 2: 377-379.

Waits, L.P., G. Luikart, and P. Taberlet. 2001 Estimating the probability of identity among genotypes in natural populations: cautions and guidelines. Molecular Ecology 10:249256.

White, G.C., and K.P. Burnham. 1999. Program MARK: survival estimation from populations of marked animals. Bird Study 46:S120-S139.

Williams, B.K., J.D. Nichols, and M.J. Conroy. 2002a. Analysis and management of animal populations: modeling, estimation, and decision making. Academic Press, San Diego.

Williams, T.M., M. Ben-David, S. Noren, M. Rutishauser, K. McDonald, and W. Heyward. 2002b. Running energetics of the North American river otter: do short legs necessarily reduce efficiency on land? Comparative Biochemistry and Physiology A 133:203-212.

Zar, J.H. 1999. Biostatistical Analysis. New Jersey, Prentice-Hall, Inc. 